\title{
Variations and determinants of carbon content in plants: a global synthesis
}

\author{
Suhui Ma ${ }^{1}$, Feng $\mathrm{He}^{2}$, Di Tian ${ }^{3}$, Dongting Zou ${ }^{1}$, Zhengbing Yan ${ }^{1}$, Yulong Yang ${ }^{4}$, Tiancheng Zhou ${ }^{4}$, Kaiyue Huang ${ }^{4}$, \\ Haihua Shen ${ }^{5}$, and Jingyun Fang ${ }^{1}$ \\ ${ }^{1}$ Department of Ecology, College of Urban and Environmental Sciences, Peking University, Beijing 100871, China \\ ${ }^{2}$ College of Life Sciences, University of Chinese Academy of Sciences, Beijing 100049, China \\ ${ }^{3}$ College of Life Sciences, Capital Normal University, Beijing 100048, China \\ ${ }^{4}$ College of Earth and Environmental Sciences, Lanzhou University, Lanzhou 730000, China \\ ${ }^{5}$ State Key Laboratory of Vegetation and Environmental Change, Institute of Botany, \\ Chinese Academy of Sciences, Beijing 100093, China
}

Correspondence: Jingyun Fang (jyfang@urban.pku.edu.cn)

Received: 25 July 2017 - Discussion started: 6 September 2017

Revised: 8 December 2017 - Accepted: 18 December 2017 - Published: 2 February 2018

\begin{abstract}
Plant carbon (C) content is one of the most important plant traits and is critical to the assessment of global $\mathrm{C}$ cycle and ecological stoichiometry; however, the global variations in plant $\mathrm{C}$ content remain poorly understood. In this study, we conducted a global analysis of the plant $\mathrm{C}$ content by synthesizing data from 4318 species to document specific values and their variation of the $\mathrm{C}$ content across plant organs and life forms. Plant organ $\mathrm{C}$ contents ranged from $45.0 \%$ in reproductive organs to $47.9 \%$ in stems at global scales, which were significantly lower than the widely employed canonical value of $50 \%$. Plant C content in leaves (global mean of $46.9 \%$ ) was higher than that in roots $(45.6 \%)$. Across life forms, woody plants exhibited higher $\mathrm{C}$ content than herbaceous plants. Conifers, relative to broad-leaved woody species, had higher $\mathrm{C}$ content in roots, leaves, and stems. Plant $\mathrm{C}$ content tended to show a decrease with increasing latitude. The life form explained more variation of the $\mathrm{C}$ content than climate. Our findings suggest that specific $\mathrm{C}$ content values of different organs and life forms developed in our study should be incorporated into the estimations of regional and global vegetation biomass $\mathrm{C}$ stocks.
\end{abstract}

\section{Introduction}

Carbon (C) is one of the most abundant elements in all living organisms (Hessen et al., 2004; Dietze et al., 2014). Plant photosynthesis transfers $\mathrm{C}$ from $\mathrm{CO}_{2}$ to the forms of biological compounds to maintain metabolic functions and build basic structures (Dietze et al., 2014; Martínez-Vilalta et al., 2016). This process creates a huge organic $C$ pool in terrestrial vegetation (Schlesinger and Bernhardt, 2013), which is usually estimated by multiplying total plant biomass by a corresponding biomass $\mathrm{C}$ conversion factor, i.e., the $\mathrm{C}$ content (Bert and Danjon, 2006; Thomas and Martin, 2012). The most widely employed $\mathrm{C}$ content in plants is $50 \%$ in the regional and global vegetation $\mathrm{C}$ stock estimations (De Vries et al., 2006; Keith et al., 2009; Lewis et al., 2009; Saatchi et al., 2011; Zhu et al., 2015, 2017). Originally, this value was calculated from an average molecular formula $\mathrm{CH}_{1.44} \mathrm{O}_{0.66}$, i.e., elemental composition of about $50 \% \mathrm{C}, 6 \%$ hydrogen, $44 \%$ oxygen, and trace amounts of several metal ions in living plant wood (Pettersen, 1984; Bert and Danjon, 2006).

However, an increasing number of studies have indicated that $\mathrm{C}$ content varied significantly among plant organs (Alriksson and Eriksson, 1998; Bert and Danjon, 2006; Yao et al., 2015), life forms (Tolunay, 2009; Fang et al., 2010; Cao and Chen, 2015), biomes (He et al., 2006; Martin and Thomas, 2011; Martin et al., 2015), and even across individuals (Elias and Potvin, 2003; Uri et al., 2012; Martin et al., 2013). Using the default value of $50 \%$ as biomass $C$ con- 
version factor which ignores the variation of $\mathrm{C}$ content may lead to biases (Zhang et al., 2009; Martin and Thomas, 2011; Rodrigues et al., 2015). For example, a change of $1 \%$ wood $\mathrm{C}$ content from the canonical value of $50 \%$ can bring up to $\sim 7 \mathrm{Pg} \mathrm{C}$ variation in global vegetation $\mathrm{C}$ stocks, which is almost equivalent to half of the vegetation $\mathrm{C}$ stocks of the continental United States (Dixon et al., 1994; Jones and O'Hara, 2016). Therefore, accurate knowledge of plant $\mathrm{C}$ content is crucial for estimating the potential magnitude of $\mathrm{C}$ sequestration in different biomes and understanding the roles of vegetation in the global C cycle (Thomas and Martin, 2012).

To reduce the uncertainty in estimation of vegetation $\mathrm{C}$ stocks, several studies have used the species-specific organ C content at regional scales (Jones and O'Hara, 2012; Rodrigues et al., 2015; Wu et al., 2017). Basically, the weighted mean C content (WMCC) of plants, especially woody plants, was useful for precise C stock estimation (Zhang et al., 2009). However, it is hard to obtain available data of $C$ content and biomass allocation for every species and organ in diverse vegetation. Combining the phylogenic, taxonomic and environment-dependent traits of species, the generalized $\mathrm{C}$ contents of specific life forms provide an alternative for realistic estimations (Thomas and Martin, 2012; Wu et al., 2017). For instance, the Intergovernmental Panel on Climate Change (IPCC, 2006) provided the wood C content of trees in tropical/subtropical forests $(47 \%)$ and temperate/boreal forests (48\% of broad-leaved trees and $51 \%$ of conifers). Although the values were more accurate than the default value of $50 \%$, errors were still introduced to $\mathrm{C}$ stock estimation in the actual application (Martin and Thomas, 2011), especially when the uncertainty that resulted from estimation using available plant $\mathrm{C}$ contents of limited specific life forms could not be eliminated (Thomas and Martin, 2012). Thus, the specific $\mathrm{C}$ contents of different life form plants require explicit consideration and application in vegetation $\mathrm{C}$ stock evaluations. In addition, exploring the biogeographic pattern and driving factors of plant $\mathrm{C}$ content will be of benefit for the elucidation of ecological stoichiometry and the mechanisms of plants' response to global change (Fyllas et al., 2009; Ordoñez et al., 2009; Zhang et al., 2012).

For the above reasons, we compiled a global dataset of plant organ $\mathrm{C}$ content to provide referable $\mathrm{C}$ contents of plant organs in different life forms. We tried to answer the following two questions: (1) how much $\mathrm{C}$ do specific plant organs contain? (2) What are the biogeographical patterns of plant $\mathrm{C}$ content and the possible driving factors?

\section{Material and methods}

\subsection{Data compilation}

We searched Google Scholar (https://scholar.google.com/), Web of Science (http://isiknowledge.com), and CNKI (China National Knowledge Infrastructure) (http://www.cnki.net/) for literatures reporting the $\mathrm{C}$ content of plants published from 1970 to 2016 . We documented 315 publications according to the following two criteria: (1) the data from natural ecosystems (including wetland and mangrove) or plantation ecosystems (including grassland and cropland) were included, while the data from laboratory or field experiments were excluded; and (2) plant $\mathrm{C}$ content detected by two commonly used methods (i.e., the $\mathrm{K}_{2} \mathrm{Cr}_{2} \mathrm{O}_{7}-\mathrm{H}_{2} \mathrm{SO}_{4}$ oxidation and the combustion methods) was included, while studies that used the default value, assumed value, or values calculated from the chemical compositions were excluded from our data compilation. In addition, we also included data of specific plant organs from the TRY database (https://www.try-db.org) (Kattge et al., 2011) (Table S1 in the Supplement).

Finally, a total of 24326 records of 4318 species in 1694 genera and 238 families were included in our global dataset (Fig. 1), in which 36.33 and $63.67 \%$ were from literatures and the TRY database, respectively. For each data record, we documented the geographical information (latitude, longitude, and altitude), Latin binomial, genus and family of species, organ (reproductive organ, root, leaf, and stem), life forms, chemical compounds (lignin and cellulose), and plant $\mathrm{C}$ content. Plant life forms were divided into five categories: herbaceous species (herb), woody plants, fern, vine, and bamboo. Data of crops were separately analyzed in the herbaceous category. The woody plants were further categorized into three groups: evergreen broad-leaved woody plants, deciduous broad-leaved woody plants, and conifers. The data with no information on life forms were documented from Flora of China (http://foc.eflora.cn), Wikipedia (https://en.wikipedia.org/wiki/Wiki/), Useful Tropical Plants (http://tropical.theferns.info), or The Plant List (http://www. theplantlist.org). In order to explore biogeographic patterns and the driving factors of $\mathrm{C}$ content of plant organs, we used the latitude and longitude of each site to extract data of climatic variables (mean annual temperature, MAT, ${ }^{\circ} \mathrm{C}$; mean annual precipitation, MAP, mm) from WorldClim (http:// www.worldclim.org/) (Hijmans et al., 2005). Given that plant $\mathrm{C}$ content might vary with the growth stages of individuals (Elias and Potvin, 2003; Uri et al., 2012; Martin et al., 2013), we recorded the averaged $\mathrm{C}$ content of herbaceous species across different growth stages.

\subsection{Statistical analyses}

We first documented statistics of plant organ $\mathrm{C}$ content for different life forms, including arithmetic mean (Mean), median (Median), standard deviation (SD), and coefficient of variation (CV) (Table 1). The $\mathrm{C}$ content of each organ showed a normal distribution (Fig. 2), and thus the onesample Student's $t$-test was used to determine whether the stem $\mathrm{C}$ content of woody plants significantly differed from the default value of $50 \%$ and the IPCC values $(47,48$, and $51 \%$ ), respectively. The two-sample Student's $t$-test was 


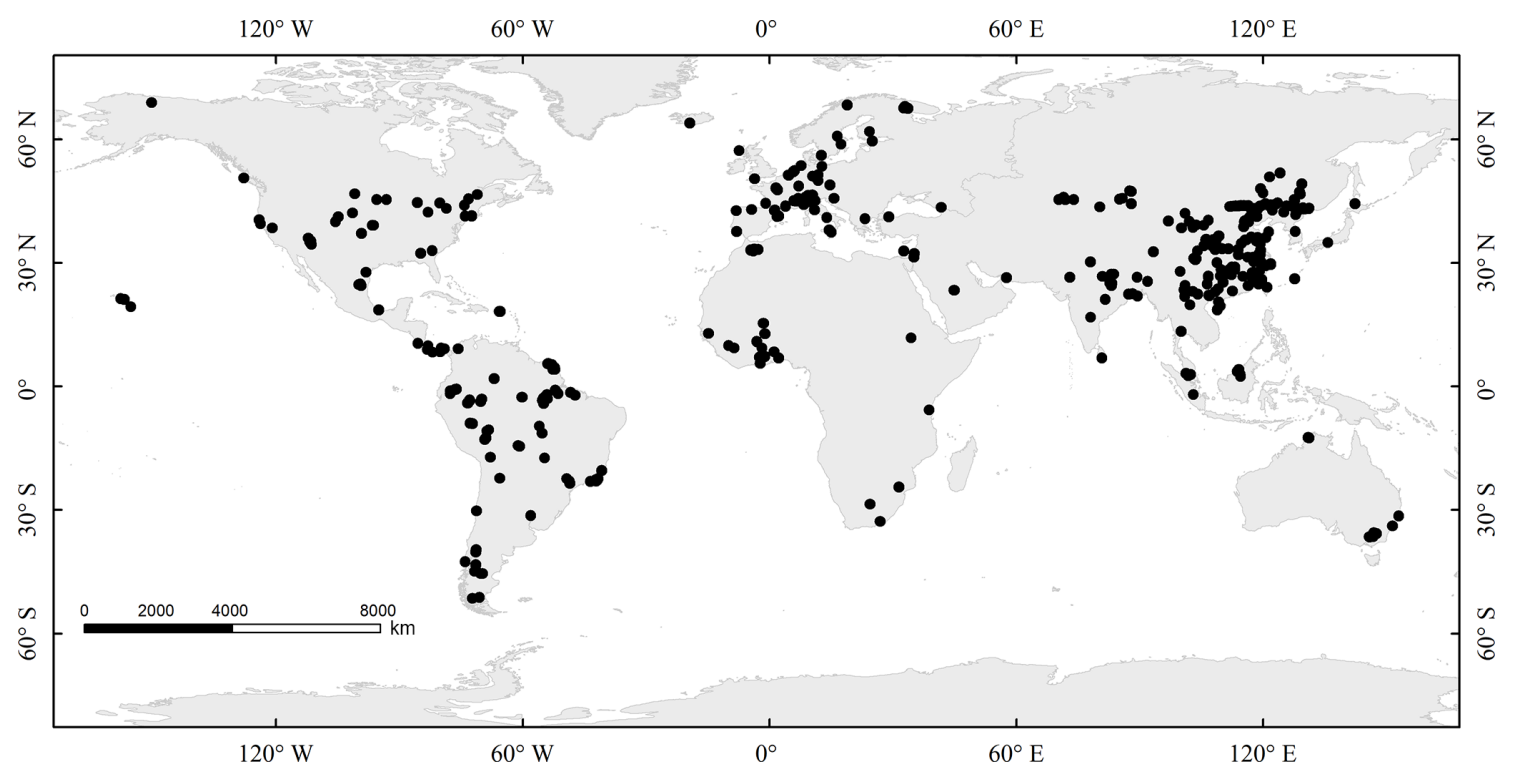

Figure 1. Geographic distribution of sample sites used in this synthesis.

Table 1. Plant carbon content (\%) in four organs across different life forms. $n$ is the sample size, and SD is the abbreviation of standard deviation. Samples for stem include the samples from shoot, stem, twig, and branch. “-” indicates no data.

\begin{tabular}{lrr|rr|rr|rr}
\hline & \multicolumn{2}{c}{ Reproductive organ } & \multicolumn{2}{c|}{ Root } & \multicolumn{2}{c}{ Leaf } & \multicolumn{2}{c}{ Stem } \\
\cline { 2 - 9 } Life form & $n$ & Mean \pm SD & $n$ & Mean \pm SD & $n$ & Mean \pm SD & $n$ & Mean \pm SD \\
\hline Herbaceous plants & 83 & $42.56 \pm 4.57$ & 749 & $42.45 \pm 5.12$ & 5181 & $44.73 \pm 3.45$ & 162 & $42.41 \pm 3.54$ \\
Crop & 42 & $42.40 \pm 5.11$ & 56 & $38.20 \pm 5.23$ & 85 & $41.32 \pm 3.38$ & 69 & $43.26 \pm 3.15$ \\
Woody plants & 57 & $48.56 \pm 4.07$ & 1392 & $47.43 \pm 3.94$ & 12064 & $47.83 \pm 3.81$ & 3461 & $48.16 \pm 3.27$ \\
Deciduous broad-leaved & 17 & $46.81 \pm 3.93$ & 513 & $46.59 \pm 3.55$ & 5074 & $47.25 \pm 3.42$ & 1581 & $47.69 \pm 2.68$ \\
Evergreen broad-leaved & 29 & $49.64 \pm 4.42$ & 520 & $47.72 \pm 4.14$ & 4490 & $48.48 \pm 3.86$ & 1212 & $47.78 \pm 3.58$ \\
Conifers & 8 & $48.25 \pm 2.56$ & 252 & $48.43 \pm 4.16$ & 560 & $50.25 \pm 3.33$ & 502 & $50.48 \pm 3.07$ \\
Fern & - & - & 2 & $43.64 \pm 3.83$ & 98 & $44.47 \pm 3.33$ & - & - \\
Vine & 2 & $45.83 \pm 0.33$ & 38 & $46.25 \pm 4.46$ & 251 & $45.74 \pm 4.77$ & 82 & $46.73 \pm 2.69$ \\
Bamboo & - & - & 23 & $45.06 \pm 4.28$ & 30 & $42.98 \pm 5.09$ & 39 & $49.20 \pm 3.54$ \\
All & 142 & $45.01 \pm 5.23$ & 2306 & $45.64 \pm 4.95$ & 18124 & $46.85 \pm 3.98$ & 3754 & $47.88 \pm 3.49$ \\
\hline
\end{tabular}

used to determine whether statistical differences of plant organ $\mathrm{C}$ content existed between different life forms. Specifically, we compared the $\mathrm{C}$ contents of herbs vs. woody plants, conifers vs. deciduous broad-leaved woody plants, and conifers vs. evergreen broad-leaved woody plants.

A linear model without accounting for other factors was used to explore biogeographical patterns of plant organ $\mathrm{C}$ content along latitudinal gradients, MAT and MAP (Han et al., 2011). To evaluate the effects of life form and climatic factors (i.e., MAT and MAP) on the variations of plant C contents, a partial generalized linear model was used to calculate the total explanation, the independent explanation, and the interactive explanation of climatic factors and life forms for different organs (i.e., reproductive organ, root, leaf, and stem)(Han et al., 2011). Additionally, a linear model and an analysis of variance (type III) were performed to test the vari- ations of $\mathrm{C}$ contents explained by climatic factors and life forms. A linear model was used to explore the relationship of plant $\mathrm{C}$ content with the content of lignin and cellulose. All statistical analyses were performed in the R 3.3.1 software ( $\mathrm{R}$ core Team, 2016).

\section{Results}

\subsection{Carbon content of plant organs}

Plant C content varied significantly among organs. Arithmetic means of $\mathrm{C}$ content for reproductive organ, root, leaf, and stem were $45.01,45.64,46.85$, and $47.88 \%$, respectively (Fig. 2, Table 1), all of which were significantly lower than the default value of $50 \%(p<0.05)$. Plant organ $\mathrm{C}$ content also varied markedly across life forms (Table 1). Among 

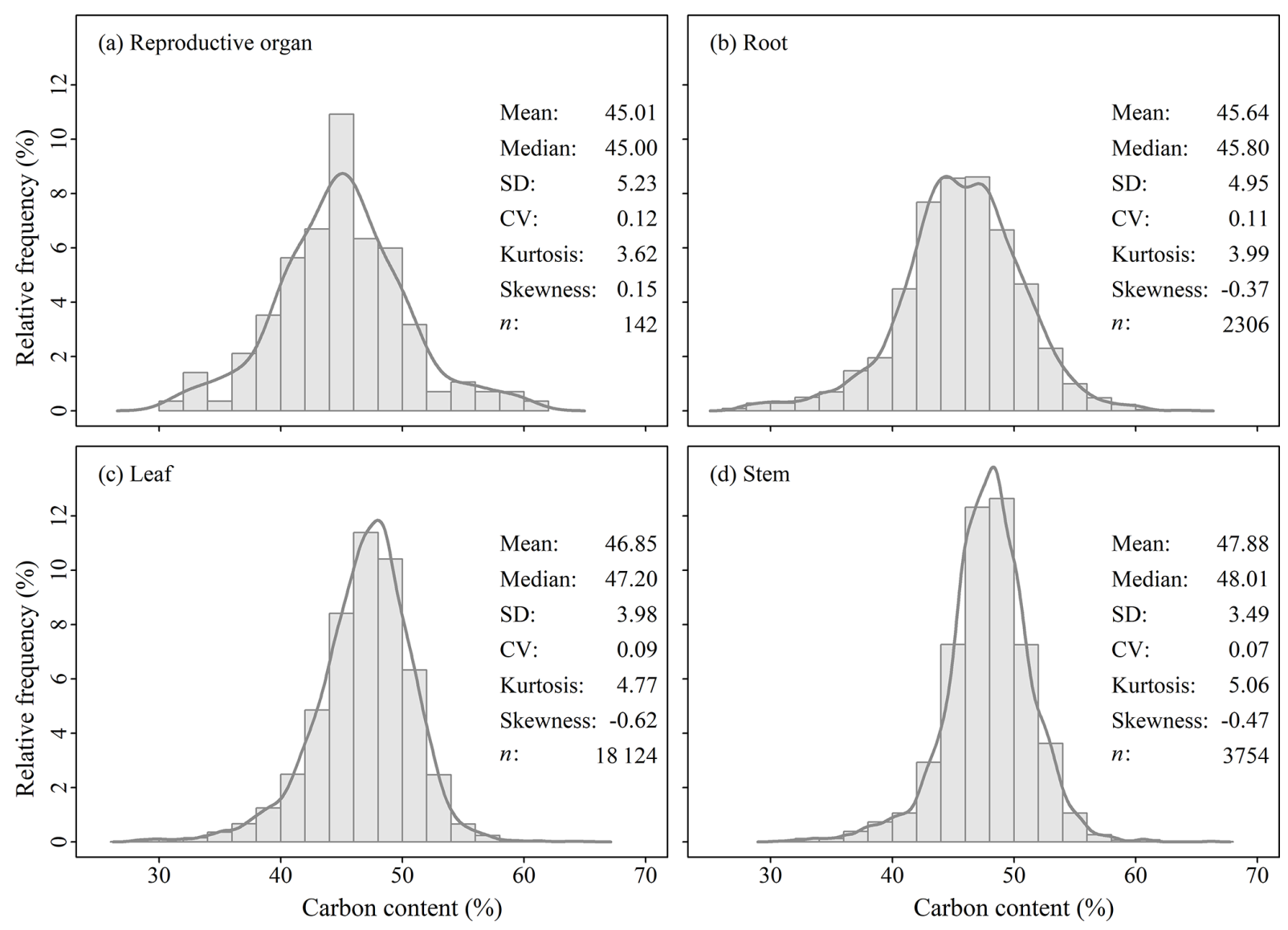

Figure 2. Histograms of carbon content of (a) reproductive organ, (b) root, (c) leaf and (d) stem. Abbreviations: SD, standard deviation; CV, coefficient of variation; $n$ indicates sample size.

herbaceous plants, $\mathrm{C}$ content ranged from $42.41 \%$ in stems to $44.73 \%$ in leaves, and among woody plants, $\mathrm{C}$ content changed from $47.43 \%$ in roots to $48.56 \%$ in reproductive organs (Table 1). C contents in all four organs were significantly higher in the woody species than in the herbaceous species. Across woody species, C contents in roots, leaves, and stems of conifers were significantly higher than those of deciduous broad-leaved and evergreen broad-leaved woody plants. In addition, the $\mathrm{C}$ contents of ferns, vines, and bamboo ranged from 42.98 to $49.20 \%$ (Table 1 ).

\subsection{Latitudinal trends of carbon content and possible driving factors}

Plant C contents in roots and leaves decreased with increasing latitude and decreasing MAT and MAP $\left(r^{2}=0.05\right.$, $p<0.001$ in all cases), while reproductive and stem $\mathrm{C}$ content displayed no significant latitudinal trends $\left(r^{2}=0.02\right.$, $p>0.05 ; r^{2}<0.01, p>0.05$; Fig. 3, Table S2).

The $\mathrm{C}$ content of plant organs was significantly affected by climatic factors $(p<0.05$ in stem), life form, and their interaction $(p<0.05$ in all cases, except for reproductive organs) (Tables S3-S6). The effects of climatic factors and life forms on plant $\mathrm{C}$ content varied largely across the plant organs (Fig. 4). The independent explanations of climatic factors on the variation in the $\mathrm{C}$ contents of the reproductive organs, roots, leaves, and stems were 8.4, 0.2, 3.8, and $0.5 \%$, respectively. The variation of $\mathrm{C}$ content in the reproductive organs, roots, leaves, and stems explained independently by life forms were $19.8,21.5,7.2$, and $10.0 \%$, respectively. The interactive explanations of climatic factors and life form on the variation of $\mathrm{C}$ content of the reproductive organs, roots, leaves, and stems were $15.7,3.6,5.2$, and $0.7 \%$, respectively. These results demonstrated that the variation of plant $\mathrm{C}$ content was explained more by life form than by climatic factors (Fig. 4; Tables S3-S6).

\section{Discussion}

We evaluated plant $\mathrm{C}$ content across plant organs and life forms by establishing a global plant $\mathrm{C}$ content dataset. Our results showed that plant $\mathrm{C}$ content varied remarkably among organs, which was consistent with previous studies (Alriksson and Eriksson, 1998; Northup et al., 2005; Tolunay, 2009). Notably, we found that the global average $C$ contents 

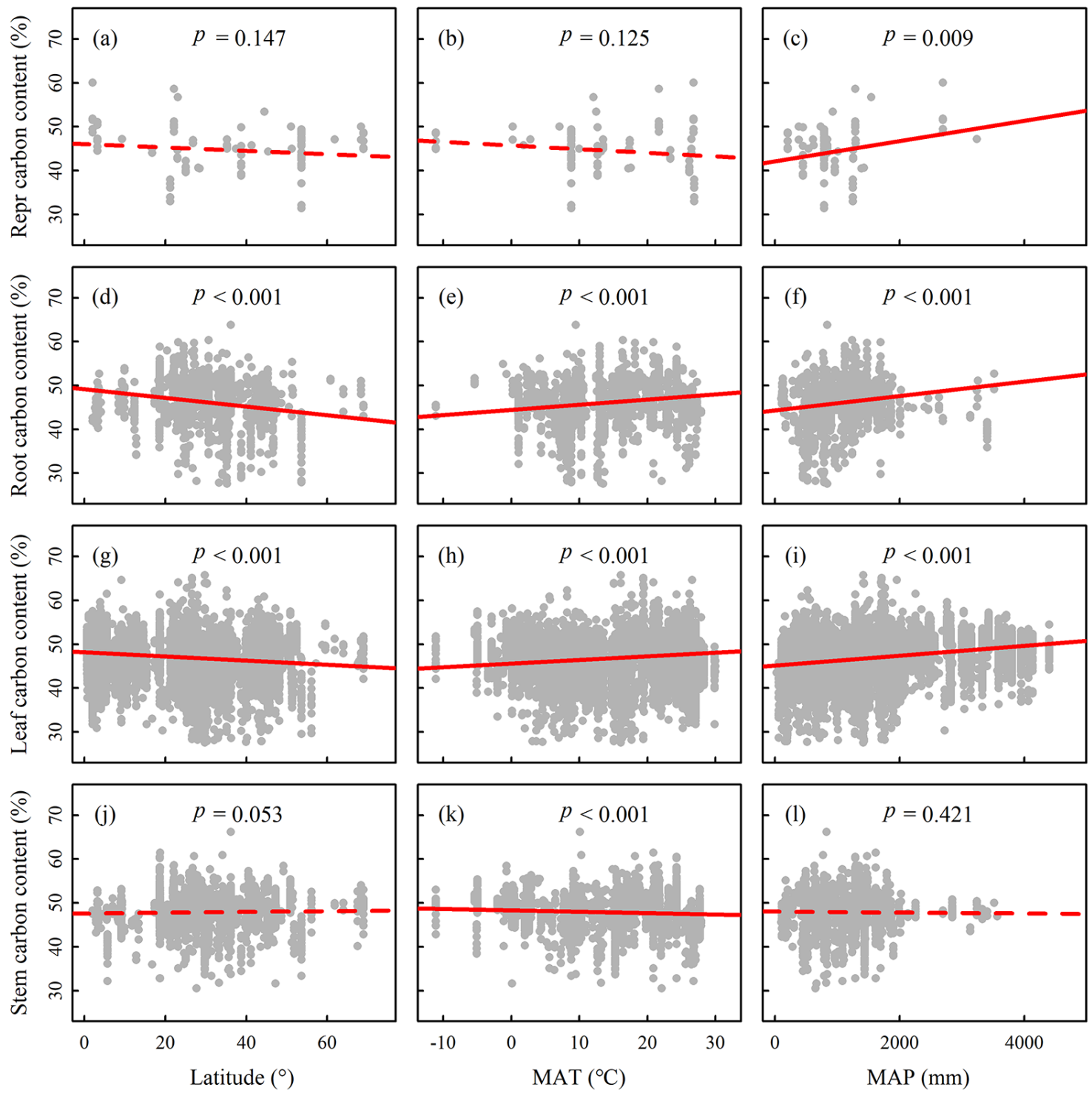

Figure 3. Trends in the plant carbon contents along latitude and climate gradients. MAT, mean annual temperature; MAP, mean annual precipitation. Ordinary least squares (OLS) regression lines are fit to the data. Solid lines indicate the significant relationships with $p<0.05$, and dashed lines denote the insignificant relationships with $p>0.05$. Abbreviations: repr carbon content refers to the reproductive organ carbon content. Plant carbon content in roots and leaves showed a significant latitudinal trend.

of four organs were significantly lower than the canonical value of $50 \%$, which was widely used to convert vegetation biomass to $\mathrm{C}$ stock at large scales, such as in temperate forests (De Vries et al., 2006), tropical forests (Lewis et al., 2009; Saatchi et al., 2011), and global forests (Keith et al., 2009). In addition, $C$ contents of stems and leaves were significantly higher than another default value of $45.45 \%$ proposed by Whittaker (1975), although the $C$ contents of roots and reproductive organs showed no significantly statistical difference. Furthermore, our results showed that plant $\mathrm{C}$ contents varied significantly among life forms (Table 1). Among woody plants, the stem $\mathrm{C}$ contents of broad-leaved woody species (i.e., $47.69 \%$ in deciduous and $47.78 \%$ in evergreen) and conifers (51.48\%) were comparable with those (47.7 and $50.8 \%$, respectively) reported by Thomas and Martin (2012). However, these data were significantly lower than the values of temperate broad-leaved woody species $(48 \% ; p<0.001$ and $p=0.018)$ and conifers ( $51 \% ; p<0.001)$, though higher than those of tropical broad-leaved woody species $(47 \%$; $p<0.001$ and $p<0.001)$ proposed by IPCC (2006). This suggested that these values from IPCC may underestimate or overestimate the stem $\mathrm{C}$ content for broad-leaved trees and conifers at global scales. 
(a) Full model for reproductive organ carbon content: 43.9 (\%)

Climate 24.1

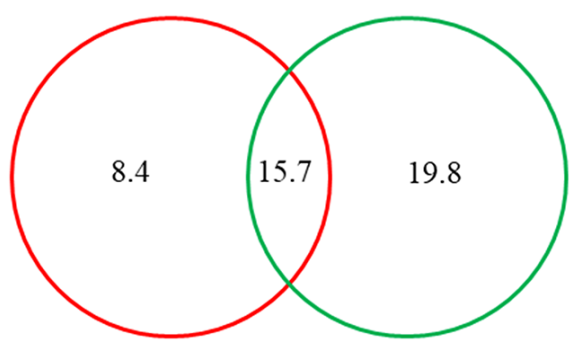

(c) Full model for leaf carbon content: $16.2(\%)$

Climate 9.0

Life form 12.4

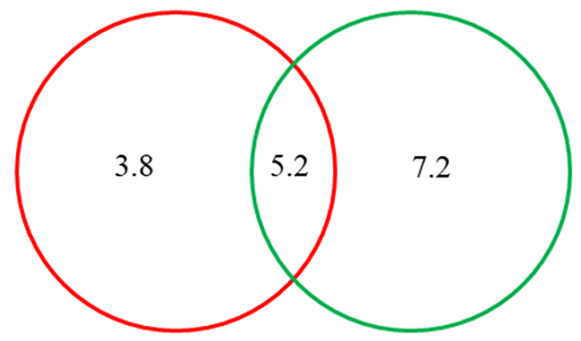

(b) Full model for root carbon content: $25.3(\%)$

Climate 3.8

Life form 25.1

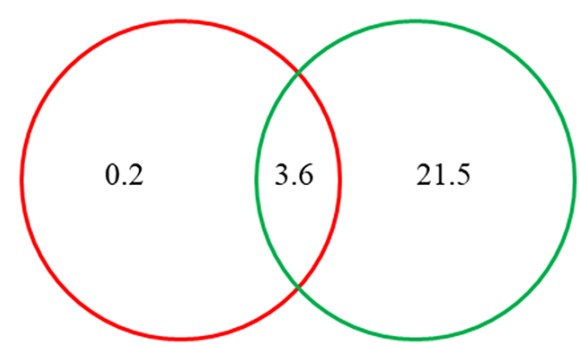

(d) Full model for stem carbon content: $11.2(\%)$

Climate 1.2 Life form 10.7

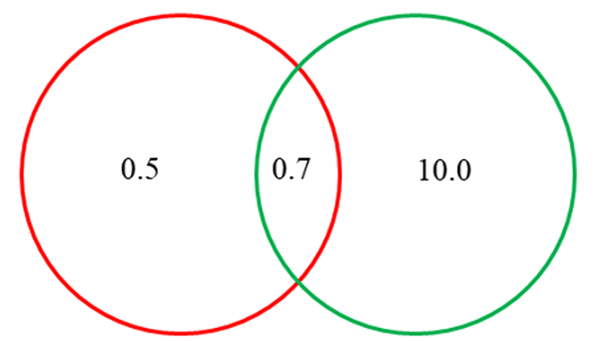

Figure 4. Variation partitioning $\left(r^{2}\right)$ of climate and life forms to account for the variation in plant carbon contents across different organs. (a) Reproductive organ, (b) root, (c) leaf, and (d) stem. Life form independently explained more variation of carbon content in each organ than climate.
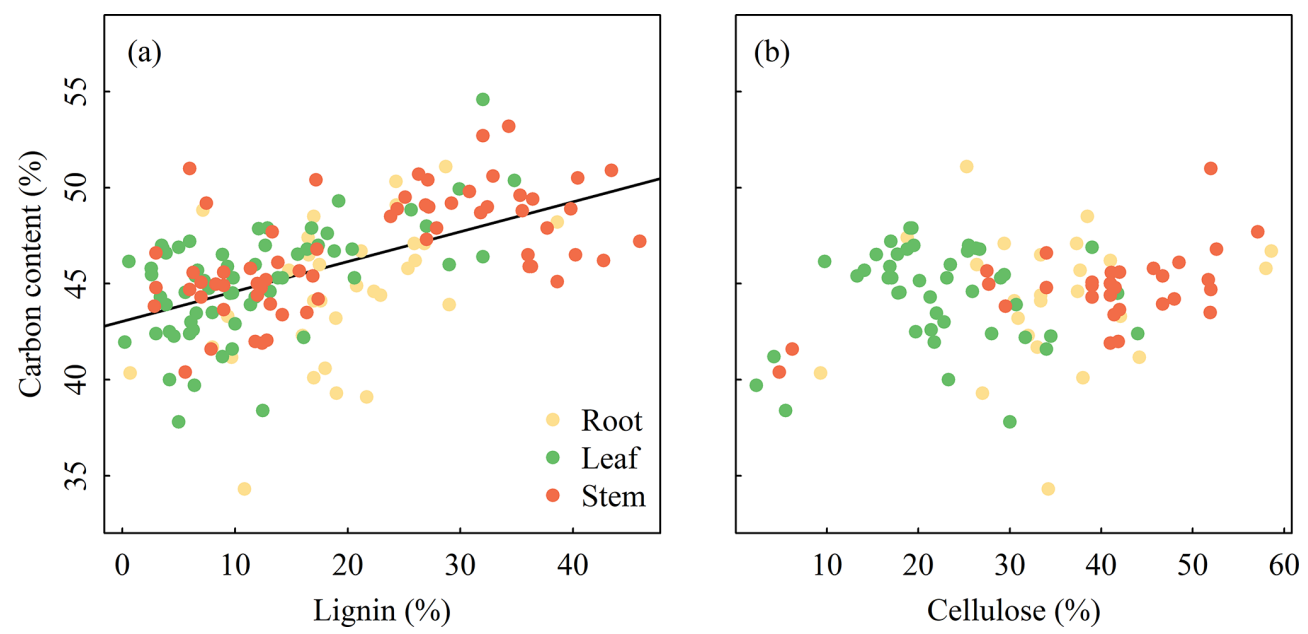

Figure 5. Relationships between plant carbon content and lignin and cellulose among three organs. Plant carbon content increases significantly with the increasing lignin in plants $\left(r^{2}=0.29, p<0.001\right)$, whereas it is not correlated with the cellulose in plants.

The variation of plant $\mathrm{C}$ content among organs and life forms was associated with differences in their chemical compositions (Figs. 5-6). Plant organs are composed of several organic compounds with different $\mathrm{C}$ content, such as lignin (with C content of 63-66\%), cellulose (with C content of about $44 \%$ ), and nonstructural carbohydrates (NSC) (e.g., sugar or starch with C content of about $44 \%$ ) (Adler, 1977;
Poorter and Bergkotte, 1992). Our result was consistent with previous findings that plant organs with higher lignin (e.g., stems) tend to have a higher $\mathrm{C}$ content than organs with lower lignin content (e.g., leaves, roots, and reproductive organs; Fig. 5a) (Savidge, 2000; Lamlom and Savidge, 2003; Bert and Danjon, 2006; Martin and Thomas, 2011). Despite the high lignin in roots, the $\mathrm{C}$ content in roots was lower than that 

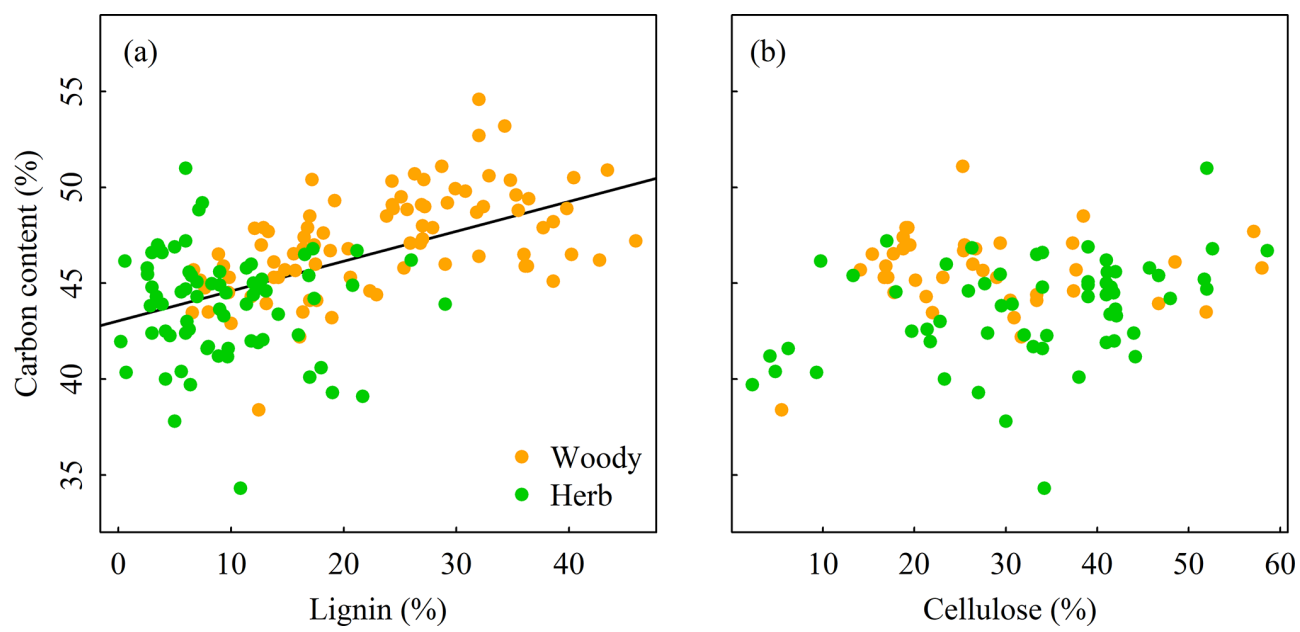

Figure 6. Relationships between plant carbon content and lignin and cellulose in woody plants and herbaceous plants. Plant carbon content increases significantly with increasing lignin in plants $\left(r^{2}=0.29, p<0.001\right)$, whereas it is not correlated with the cellulose in plants.

in leaves, probably because of the high proportions of protein and other C-rich compounds in leaves (Rouwenhorst et al., 1991; Niinemets et al., 2002) and high content of starch in roots (Bert and Danjon, 2006). The lowest C content in reproductive organs was consistent with its high quantities of NSC and low content of lignin (Barros et al., 1996). Across life forms, woody plants generally require proportionally greater investments of $\mathrm{C}$ at the cellular level to synthesize lignin to support structures with relatively low growth rate, which result in high lignin and $\mathrm{C}$ content (Fig. 6a). In contrast, the high relative growth rate of herbs is accordant with their low lignin and $\mathrm{C}$ content (Armstrong et al., 1950; Johnson et al., 2007). Furthermore, the difference in stem $C$ contents of broad-leaved woody plants (i.e., 47.69 and $47.78 \%$ for deciduous and evergreen species, respectively) and conifers $(50.48 \%)$ could also be explained by their corresponding differences in chemical compositions (Lamlom and Savidge, 2003; Thomas and Martin, 2012).

Our results showed that $\mathrm{C}$ contents in roots and leaves decreased significantly with increasing latitude (Fig. 3). This was inconsistent with previous studies reporting that $\mathrm{C}$ content of global plant fine root showed no latitudinal trend (Yuan et al., 2011) but was consistent with the latitudinal trends of plant $\mathrm{C}$ contents of roots and leaves in China's forests (Zhao et al., 2016). Generally, climatic factors (i.e., temperature and precipitation) regulate elemental contents in plant organs by influencing the associated plant metabolism and functioning (Reich and Oleksyn, 2004; Reich, 2005; Zhang et al., 2012). In our study, climatic factors explained independently less variation of plant $\mathrm{C}$ contents of four organs (0.2-8.4\%, see Fig. 4) than other factors. The climatic factors and life form together explained higher proportion of the variation in $\mathrm{C}$ contents of roots and leaves (25.3 and $16.2 \%$ in Fig. 4), while both the independent effect of climatic factors and the interactive effect of climate and life form on the $\mathrm{C}$ content of stem were lower $(0.5$ and $0.7 \%$, respectively) than those of other organs. This may be one reason for the lack of significant latitudinal trend for $\mathrm{C}$ content in stems.

Our data showed that the life form independently explained more variation of plant $\mathrm{C}$ content of four organs (7.2-21.5\%, Fig. 4), which was consistent with the results of Fyllas et al. (2009) and other studies about plant nutrient stoichiometry at global scales (Han et al., 2011; Zhao et al., 2016; Tian et al., 2017). Further, the interactive effects of climatic factors with life forms were higher than the independent explanations of climate $(0.7-15.7 \%$, Fig. 4). These results conjointly revealed the important role of plant life form in shaping plant $\mathrm{C}$ content, which implied that the shift of species composition in regional vegetation along the latitudinal gradients influenced by climate could partly explain the biogeographic pattern of plant $\mathrm{C}$ content. Generally, the proportion of woody plants tends to a decrease while that of herbs increases with increasing latitude and decreasing MAT and MAP (Fig. S1 in the Supplement). Hence, the variation in life forms grouping in different biomes further corroborates our results of the biogeographic pattern of plant $\mathrm{C}$ content.

\section{Conclusions}

Plant C content varied with organs and life forms at global scales. Specifically, plant C content in leaves was higher than that in roots. Across life forms, woody plants exhibited higher $\mathrm{C}$ content than herbaceous plants. Using the canonical values of $50 \%$ may underestimate and overestimate the $\mathrm{C}$ content in stems and leaves of conifers and in all organs of other life forms, respectively. Thus, specific plant $\mathrm{C}$ contents given in Table 1 provided an alternative to IPCC for their guidelines to update the plant $\mathrm{C}$ fractions and could improve the accuracy of vegetation $\mathrm{C}$ stock estimations. Furthermore, 
plant $\mathrm{C}$ content showed significant latitudinal trends induced by climatic factors and life forms. This suggests that these latitudinal trends and driving factors should be incorporated into the research of plant ecological stoichiometry and biogeochemical modeling.

Data availability. Data used in this study can be found in the Supplement.

\section{The Supplement related to this article is available online at https://doi.org/10.5194/bg-15-693-2018-supplement.}

Competing interests. The authors declare that they have no conflict of interest.

Acknowledgements. This work was supported by the National Natural Science Foundation of China (31330012, 31621091). We thank Peng Li, Chengjun Ji, and Zhiyao Tang for their helpful suggestions for data collection and analysis. We thank Aaron Hogan, Anwar Eziz, Jianxiao Zhu, Qiong Cai, and Ming Ouyang for a friendly review of the manuscript. We also thank the TRY initiative on plant traits (http://www.try-db.org). The TRY database is hosted at the Max Planck Institute for Biogeochemistry (Jena, Germany) and supported by DIVERSITAS/Future Earth, the German Centre for Integrative Biodiversity Research (iDiv) Halle-Jena-Leipzig, and EU project BACI (grant ID 640176).

Edited by: Akihiko Ito

Reviewed by: two anonymous referees

\section{References}

Adler, E.: Lignin chemistry - past, present and future, Wood Sci. Technol., 11, 169-218, 1977.

Alriksson, A. and Eriksson, H. M.: Variations in mineral nutrient and $\mathrm{C}$ distribution in the soil and vegetation compartments of five temperate tree species in NE Sweden, Forest Ecol. Manag., 108, 261-273, 1998 .

Armstrong, D., Cook, H., and Thomas, B.: The lignin and cellulose contents of certain grassland species at different stages of growth, J. Agr. Sci., 40, 93-99, 1950.

Barros, R. S., Finger, F. L., and Magalhães, M. M.: Changes in nonstructural carbohydrates in developing fruit of Myrciaria jaboticaba, Sci. Hortic., 66, 209-215, 1996.

Bert, D. and Danjon, F.: Carbon concentration variations in the roots, stem and crown of mature Pinus pinaster (Ait.), Forest Ecol. Manag., 222, 279-295, 2006.

Cao, Y. and Chen, Y. M.: Biomass, Carbon and nutrient storage in a 30-year-old Chinese cork oak (Quercus Variabilis) forest on the south slope of the qinling mountains, China, Forests, 6, 1239$1255,2015$.
De Vries, W., Reinds, G. J., Gundersen, P., and Sterba, H.: The impact of nitrogen deposition on carbon sequestration in European forests and forest soils, Glob. Change Biol., 12, 1151-1173, 2006.

Dietze, M. C., Sala, A., Carbone, M. S., Czimczik, C. I., Mantooth, J. A., Richardson, A. D., and Vargas, R.: Nonstructural carbon in woody plants, Annu. Rev. Plant Biol., 65, 667-687, 2014.

Dixon, R. K., Solomon, A. M., Brown, S., Houghton, R. A., Trexier, M. C., and Wisniewski, J.: Carbon pools and flux of global forest ecosystems, Science, 263, 185-190, 1994.

Elias, M. and Potvin, C.: Assessing inter-and intra-specific variation in trunk carbon concentration for 32 neotropical tree species, Can. J. Forest Res., 33, 1039-1045, 2003.

Fang, S. Z., Li, H. L., Sun, Q. X., and Chen, L. B.: Biomass production and carbon stocks in poplar-crop intercropping systems: a case study in northwestern Jiangsu, China, Agroforest Syst., 79, 213-222, 2010.

Fyllas, N. M., Patiño, S., Baker, T. R., Bielefeld Nardoto, G., Martinelli, L. A., Quesada, C. A., Paiva, R., Schwarz, M., Horna, V., Mercado, L. M., Santos, A., Arroyo, L., Jiménez, E. M., Luizão, F. J., Neill, D. A., Silva, N., Prieto, A., Rudas, A., Silviera, M., Vieira, I. C. G., Lopez-Gonzalez, G., Malhi, Y., Phillips, O. L., and Lloyd, J.: Basin-wide variations in foliar properties of Amazonian forest: phylogeny, soils and climate, Biogeosciences, 6 , 2677-2708, https://doi.org/10.5194/bg-6-2677-2009, 2009.

Han, W. H., Fang, J. Y., Reich, P. B., Ian Woodward, F., and Wang, Z. H.: Biogeography and variability of eleven mineral elements in plant leaves across gradients of climate, soil and plant functional type in China, Ecol. Lett., 14, 788-796, 2011.

He, J. S., Fang, J. Y., Wang, Z. H., Guo, D. L., Flynn, D. F., and Geng, Z.: Stoichiometry and large-scale patterns of leaf carbon and nitrogen in the grassland biomes of China, Oecologia, 149, 115-122, 2006.

Hessen, D. O., Ågren, G. I., Anderson, T. R., Elser, J. J., and de Ruiter, P. C.: Carbon sequestration in ecosystems: the role of stoichiometry, Ecology, 85, 1179-1192, 2004.

Hijmans, R. J., Cameron, S. E., Parra, J. L., Jones, P. G., and Jarvis, A.: Very high resolution interpolated climate surfaces for global land areas, Int. J. Climatol., 25, 1965-1978, 2005.

IPCC: Forest lands, Intergovernmental Panel on Climate Change Guidelines for National Greenhouse Gas Inventories, Institute for Global Environmental Strategies (IGES), Hayama, Japan, 2006.

Johnson, J. M. F., Barbour, N. W., and Weyers, S. L.: Chemical composition of crop biomass impacts its decomposition, Soil Sci. Soc. Am. J., 71, 155-162, 2007.

Jones, D. A. and O'Hara, K. L.: Carbon density in managed coast redwood stands: implications for forest carbon estimation, Forestry, 85, 99-110, 2012.

Jones, D. A. and O'Hara, K. L.: The influence of preparation method on measured carbon fractions in tree tissues, Tree Physiol., 36, 1177-1189, https://doi.org/10.1093/treephys/tpw051, 2016.

Kattge, J., Diaz, S., Lavorel, S., et al.: TRY-a global database of plant traits, Glob. Change Biol., 17, 2905-2935, 2011.

Keith, H., Mackey, B. G., and Lindenmayer, D. B.: Re-evaluation of forest biomass carbon stocks and lessons from the world's most carbon-dense forests, P. Natl. Acad. Sci. USA, 106, 1163511640, 2009. 
Lamlom, S. H. and Savidge, R. A.: A reassessment of carbon content in wood: variation within and between 41 North American species, Biomass Bioenerg., 25, 381-388, 2003.

Lewis, S. L., Lopez-Gonzalez, G., Sonke, B., Affum-Baffoe, K., Baker, T. R., Ojo, L. O., Phillips, O. L., Reitsma, J. M., White, L., Comiskey, J. A., Djuikouo, M. N., Ewango, C. E. N., Feldpausch, T. R., Hamilton, A. C., Gloor, M., Hart, T., Hladik, A., Lloyd, J., Lovett, J. C., Makana, J. R., Malhi, Y., Mbago, F. M., Ndangalasi, H. J., Peacock, J., Peh, K. S. H., Sheil, D., Sunderland, T., Swaine, M. D., Taplin, J., Taylor, D., Thomas, S. C., Votere, R., and Woll, H.: Increasing carbon storage in intact African tropical forests, Nature, 457, 1003-1006, 2009.

Martin, A. R. and Thomas, S. C.: A reassessment of carbon content in tropical trees, Plos One, 6, e23533, https://doi.org/10.1371/journal.pone.0023533, 2011.

Martin, A. R., Thomas, S. C., and Zhao, Y.: Size-dependent changes in wood chemical traits: a comparison of neotropical saplings and large trees, AOB Plants, 5, plt039, https://doi.org/10.1093/aobpla/plt039, 2013.

Martin, A. R., Gezahegn, S., and Thomas, S. C.: Variation in carbon and nitrogen concentration among major woody tissue types in temperate trees, Can. J. Forest Res., 45, 744-757, 2015.

Martínez-Vilalta, J., Sala, A., Asensio, D., Galiano, L., Hoch, G., Palacio, S., Piper, F. I., and Lloret, F.: Dynamics of nonstructural carbohydrates in terrestrial plants: a global synthesis, Ecol. Monogr., 86, 495-516, 2016.

Niinemets, Ü., Ellsworth, D. S., Lukjanova, A., and Tobias, M.: Dependence of needle architecture and chemical composition on canopy light availability in three North American Pinus species with contrasting needle length, Tree Physiol., 22, 747-761, 2002.

Northup, B., Zitzer, S., Archer, S., McMurtry, C., and Boutton, T.: Above-ground biomass and carbon and nitrogen content of woody species in a subtropical thornscrub parkland, J. Arid Environ., 62, 23-43, 2005

Ordoñez, J. C., Bodegom, P. M. V., Witte, J. P. M., Wright, I. J., Reich, P. B., and Aerts, R.: A global study of relationships between leaf traits, climate and soil measures of nutrient fertility, Global Ecol. Biogeogr., 18, 137-149, 2009.

Pettersen, R. C.: The chemical composition of wood, in: The Chemistry of Wood. Advances in Chemistry Series 207, edited by: Rowel, R. M., ACS Publications, Washington, DC, USA, 57126, 1984

Poorter, H. and Bergkotte, M.: Chemical composition of 24 wild species differing in relative growth rate, Plant Cell Environ., 15, 221-229, 1992.

R Core Team: A language and environment for statistical computing. R Foundation for Statistical Computing, Vienna, Austria, https://www.R-project.org/, 2016.

Reich, P. B.: Global biogeography of plant chemistry: filling in the blanks, New Phytol., 168, 263-266, 2005.

Reich, P. B. and Oleksyn, J.: Global patterns of plant leaf N and P in relation to temperature and latitude, P. Natl. Acad. Sci. USA, 101, 11001-11006, 2004.

Rodrigues, D. P., Hamacher, C., Estrada, G. C. D., and Soares, M. L. G.: Variability of carbon content in mangrove species: Effect of species, compartments and tidal frequency, Aquat. Bot., 120, 346-351, 2015.
Rouwenhorst, R. J., Jzn, J. F., Scheffers, W. A., and van Dijken, J. P.: Determination of protein concentration by total organic carbon analysis, J. Biochem. Bioph. Meth., 22, 119-128, 1991.

Saatchi, S. S., Harris, N. L., Brown, S., Lefsky, M., Mitchard, E. T., Salas, W., Zutta, B. R., Buermann, W., Lewis, S. L., and Hagen, S.: Benchmark map of forest carbon stocks in tropical regions across three continents, P. Natl. Acad. Sci. USA, 108, 9899-9904, 2011.

Savidge, R.: Biochemistry of seasonal cambial growth and wood formation-an overview of the challenges, in: Cell and molecular biology of wood formation. Experimental Biology Reviews, edited by: Savidge, R., Barnett, J. R., and Napier, R., BIOS Scientific Publishers Ltd., Oxford, UK, 1-30, 2000.

Schlesinger, W. H. and Bernhardt, E. S.: Chapter 5 - The Biosphere: The Carbon Cycle of Terrestrial Ecosystems, in: Biogeochemistry: An Analysis of Global Change, 3rd Edition, Academic Press, Boston, MA, USA, 135-171, 2013.

Thomas, S. C. and Martin, A. R.: Carbon content of tree tissues: a synthesis, Forests, 3, 332-352, 2012.

Tian, D., Yan, Z. B., Niklas K. J., Han, W. X., Kattge, J., Reich, P. B., Luo, Y. K., Chen, Y. H., Tang, Z. Y., Hu, H. F., Wright, I. J., Schmid, B., and Fang, J. Y.: 2017. Global leaf nitrogen and phosphorus stoichiometry and their scaling exponent, Natl. Sci. Rev., nwx142, https://doi.org/10.1093/nsr/nwx142, 2017.

Tolunay, D.: Carbon concentrations of tree components, forest floor and understorey in young Pinus sylvestris stands in northwestern Turkey, Scand. J. Forest Res., 24, 394-402, 2009.

Uri, V., Varik, M., Aosaar, J., Kanal, A., Kukumägi, M., and Lõhmus, K.: Biomass production and carbon sequestration in a fertile silver birch (Betula pendula Roth) forest chronosequence, Forest Ecol. Manag., 267, 117-126, 2012.

Whittaker, R. H.: Communities and Ecosystems, 2nd Revise Edition, MacMillan Publishing Co., New York, USA, 1975.

Wu, H. L., Xiang, W. H, Fang, X., Lei, P. F., Ouyang, S. and Deng, X. W.: Tree functional types simplify forest carbon stock estimates induced by carbon concentration variations among species in a subtropical area, Sci. Rep., 7, 4992, https://doi.org/10.1038/s41598-017-05306-z, 2017.

Yao, F. Y, Chen, Y. H, Yan, Z. B, Li, P., Han, W. X, and Fang, J. Y.: Biogeographic patterns of structural traits and $\mathrm{C}: \mathrm{N}: \mathrm{P}$ stoichiometry of tree twigs in China's forests, Plos One, 10, e0116391, https://doi.org/10.1371/journal.pone.0116391, 2015.

Yuan, Z. Y., Chen, H. Y. H., and Reich, P. B.: Global-scale latitudinal patterns of plant fine-root nitrogen and phosphorus, Nat Commun., 2, 344, https://doi.org/10.1038/ncomms1346, 2011.

Zhang, Q. Z., Wang, C. K., Wang, X. C., and Quan, X. K.: Carbon concentration variability of 10 Chinese temperate tree species, Forest Ecol. Manag., 258, 722-727, https://doi.org/10.1016/j.foreco.2009.05.009, 2009.

Zhao, N., Yu, G. R., He, N. P., Wang, Q. F., Guo, D. L., Zhang, X. Y., Wang, R. L., Xu, Z. W., Jiao, C. C., Li, N. N., and Jia, Y. L.: Coordinated pattern of multi-element variability in leaves and roots across Chinese forest biomes, Global Ecol. Biogeogr., 25, 359-367, 2016.

Zhu, J. X., Hu, X. Y., Yao, H., Liu, G. H., Ji, C. J., and Fang, J. Y.: A significant carbon sink in temperate forests in Beijing: based on 20-year field measurements in three stands, Sci. China Life Sci., 58, 1135-1141, 2015. 
Zhu, J. X., Hu, H. F., Tao, S. L., Chi, X. L., L, P., Jiang, L., Zhu, J. L., Tang, Z. Y., Pan, Y. D., Birdsey R. A., He, X. H., and Fang, J. Y.: Carbon stocks and changes of dead organic matter in China's forests, Nat. Commun., 8, 151, https://doi.org/10.1038/s41467017-00207-1, 2017. 